\title{
Selected Poetry (Poezje wybrane)
}

Author: Czesław Miłosz

First Published: 1943

Translations: (in selection) German (Lied vom Weltende, 1966; Zeichen im Dunkel, 1979; Gedichte 1933-1981, 1982); English (Selected Poems, 1973; Bells in Winter, 1978; The Collected Poems. 1931-1987, 1988); French (Enfant d'Europe et autres poèmes, 1980; Poèmes 1934-1982, 1984; Terre inépuisable, 1988); Hebrew (Wezarah ha-shemesh uwa ha-shemesh wesrihim aherim, 1981); Russian (Poetičeskij traktat, 1982; Tak malo i drugije stichotvorenija. 1934-1990, 1993); Spanish (Antologia poética, 1984; Poemas, 1984).

About the Author: Czesław Miłosz (1911-2004) was a poet, prose writer, essayist, translator, lecturer on literature, and winner of the 1980 Nobel Prize in Literature. He spent his childhood in Russia (1914-1918), including a period in Siberia. While studying law at Vilnius University, Miłosz also belonged to Żagary, a group of Polish poets based in Vilnius whose work was characterised by a fascination with catastrophe ( $\dot{z} a$ gary in the local Vilnius dialect means "brushwood"). His first collection of poetry, $A$ Poem on Frozen Time, was published in 1933. Oskar Miłosz, a French-language poet and distant relative, had a decisive influence on his development as a poet. During the Nazi occupation, Czesław Miłosz participated in the underground literary and cultural life in Warsaw. After the war, he published the collection Rescue (1945) - widely considered to be one of the most important volumes of Polish poetry of the 20th century -, followed by A Treatise on Morality (1948). In the postwar years, following a period of diplomatic work in New York, Washington, and Paris, he sought political asylum in France, and worked with the Paris opposition magazine Kultura, where he first published the essay The Captive Mind (1953). In 1960 he moved to Berkeley, California, where he worked as a professor at the University of California. Under the Communist regime in Poland, Miłosz's writings were only available in foreign editions, and starting in 1976 - the underground samizdat. Miłosz's 1980 Nobel Prize led finally to the publication of many of his works in Poland that had previously been banned. He returned to Poland for a visit in 1981, and returned to live there on a part-time basis starting in 1989.

Further Important Publications: Traktat moralny (1948, A Treatise on Morality, poem); Dolina Issy (1955, The Issa Valley; novel); Traktat poetycki (1957, A Treatise on Poetry; poem); Ziemia Ulro (1977, The Ulro Land; essay); To (2000, It; poems); Druga przestrzeń (2002, The Second Space; poems); Wiersze ostatnie (2006, The Last Poems; poems).

Ә Open Access. () 2021 Katarzyna Kuczyńska-Koschany, published by De Gruyter. (c))BY-NC-ND This work is licensed under a Creative Commons Attribution-NonCommercial-NoDerivatives 4.0 License. https://doi.org/10.1515/9783110671056-090 


\section{Content and Interpretation}

In the collection Rescue (1945), Miłosz initiates a reflection on the Holocaust he would carry on for many years, not only in his poetic works but also in essays and journalism, as well as public activity - as he did in 1946, for example, when he informed his American counterparts at the Polish Consulate in New York of the Warsaw Ghetto Uprising (Franaszek, 2011, pp. 288-289). Rescue remains one of the most important works of Holocaust poetry in the Polish language, and includes such masterpieces as Campo dei Fiori and A Poor Christian Looks at the Ghetto. As the poet comments elsewhere, "under such circumstances where those who help the victims of persecution themselves face capital punishment, judgment is not easy. [...] Religious motivation...personal courage, neighbourly bonds and self-enrichment collide with physical inability, fear, or lack of interest” (Kuczyńska-Koschany, 2013, pp. 142-143). Both Campo dei Fiori and A Poor Christian Looks at the Ghetto were reprinted in an anthology edited by M. M. Borwicz (1947, pp. 121-123) $\rightarrow$ The Song Will Survive... Yet they are very different poems: "The poems [...] are juxtaposed to one another as order is to chaos, or as beauty, which we are also accustomed to consider as good, is to evil - the ugliness of chaos” (Łukasiewicz, 2000, p. 142). Campo dei Fiori, as Miłosz himself defined it, is a work of "moral journalism” (Miłosz, Gorczyńska, 2002, p. 67) from which one may draw certain conclusions: "first of all, the horror of Nazism, and secondly, an attitude of indifference on the streets of Warsaw. [...] The question is: is this really how it was on the streets of Warsaw? It was and it wasn't. It was, on the one hand, because carousels really were turning just outside the periphery of the ghetto. It wasn't, because in other areas of Warsaw the streets were different. So it's not an accusation. On the other hand, it is a poem written as an ordinary human impulse in the spring of 1943" (pp. 67-68). Other works of note selected for this edition include The Journey, which closes with the words "Night Continues" ("Dalej jest noc", used as the title of one of the most shocking collections of documents about Shoah in Poland; compare: Engelking, Grabowski, 2018), Christmas Eve, and The Waltz, as well as Song on Porcelain (1953), fragments of A Treatise on Morality (1948), and A Treatise on Poetry (1957). It is also worth mentioning The Spirit of History, which gives a shocking account based - as Miłosz himself confirmed - on real events (Kuczyńska-Koschany, 2013, p. 134): "In the suburb all night / An old Jew dies, thrown into a clay pit pond / His roar only stops in the early morning". A later poem, "It", which is the title poem from a collection published in 2000, seems to refer to the same incident: "similar to when a trapped Jew sees the approaching / heavy helmets of German gendarmes”.

\section{Main Topics and Problems}

Miłosz's place among the writers and luminaries whose works have kept the memory of the Holocaust alive - or more broadly, the memory of twentieth-century totalitarianism - is evident not only in his poems, essays, and interviews, but also in his dialogues with Jewish artists (Awrom Suckewer, David Weinfeld; see Szymaniak, Szyba, 2011), as well as his long-running dialogue with Tadeusz Różewicz ( $\rightarrow$ An Excursion to 
the Museum), who asked what possible form remains for Polish poetry after Shoah. Among the most important problems raised by Miłosz are: the topos of the carousel at Krasińskis Square in Campo dei Fiori (next to the burning ghetto in 1943 - a symbol of Polish indifference towards the persecution of Jews); the figure of self-accusation, guilt and shared responsibility in "the helpers of death / The uncircumcised" in A Poor Christian Looks at the Ghetto; numerous visions of the fragility of a single person pitted against the violence of totalitarian systems; above all Nazism and the metaphysical question unde malum? in relation to sources of culture - the character of Job, for example, in all of its existential, theological, and philosophical aspects; and finally, the testimonial power of poetry in confrontation with totalitarianism - both Nazism and Stalinism -, as in his poem You Who Wronged. The situation in Miłosz's poem A Poor Christian Looks at the Ghetto is echoed by Bohdan Zadura in A Matter of Time (Kwestia czasu, 2006) when he writes, “A poor Christian / looking at the ghetto // And it serves him right”. Observations like these convey the difficulty of any kind of selfcritical assimilation of the memory of the Holocaust in Poland.

\section{Cited Works}

Błoński, J. (1994). Biedni Polacy patrza na getto. Kraków: Wydawnictwo Literackie. Błoński, J. (1998). Miłosz jak świat. Kraków: Wydawnictwo Literackie. Borwicz, M., ed. (1947). Pieśń ujdzie cało...Antologia wierszy o Żydach pod okupacją niemiecką. Łódź: Centralna Żydowska Komisja Historyczna, pp. 121-123. Engelking, B., Grabowski, J. (2018). Dalej jest noc, t. 1-2. Warszawa: Stowarzyszenie Centrum Badań nad Zagładą Żydów. Franaszek, A. (2011). Miłosz. Biografia. Kraków: Znak. Kuczyńska-Koschany, K. (2013). Miłosz czytany po Jedwabnem. In: K. Kuczyńska-Koschany, „Vse poety židy“. Antytotalitarne gesty poetyckie i kreacyjne wobec Zagłady oraz innych doświadczeń granicznych. Poznań: Wydawnictwo Naukowe UAM, pp. 123-145. Łukasiewicz, J. (2000). Przestrzeń „Świata naiwnego“. O poemacie Czesława Miłosza „Świat“. In: Poznawanie Miłosza 2. Część pierwsza: 1980-1998. Kraków: Wydawnictwo Literackie, p. 142. Miłosz, C., Gorczyńska, R. (2002). Miłosz, C. Przypis po latach. In: R. Gorczyńska, Podróżny świata. Kraków: Wydawnictwo Literackie. Szymaniak, K., Szyba, A. (2011). Dialog poetów [Czesław Miłosz, Awrom Suckewer, Dawid Weinfeld]. Warszawa: Fundacja Shalom.

\section{Further References}

Czachowska, J. (1997). Czesław Miłosz. In: J. Czachowska, A. Szałagan, eds., Współcześni polscy pisarze i badacze literatury. Tom piąty: L-M. Warszawa: Wydawnictwa Szkolne i Pedagogiczne, pp. 405-425. Davie, D. (1986). C. M. and the Insufficiency of Lyric. Knoxville: University of Tennessee Press. Fiut, A. (1987). Moment wieczny. Poezja Czesława Miłosza. Paris: Libella. Fiut, A. (2003). W stronę Miłosza. Kraków: Wydawnictwo Literackie. Iribarne, L. (1978). The Naming of Hell. Times Literary Supplement, 25.08.1978. Kopiński, A. (2004). Ludzie $z$ charakterami. O okupacyjnym sporze Czesława Miłosza i Andrzeja Trzebińskiego. Warszawa: Fronda. Nathan, L., Quinn, A., eds. 
(1991). The Poet's Work: An Introduction to C. M. Cambridge: Harvard University Press. Partisan Review (1981). Special M. Issue, 66(1). Skwarnicki, M. (2004). Mój Miłosz. Kraków: Biały Kruk. Updike, J., Survivor/Believer. The New Yorker, 24-31, December 2001. World Literature Today (1978). Special M. Issue, 52(3). Zaleski, M. (2005). Zamiast: o twórczości Czesława Miłosza. Kraków: Wydawnictwo Literackie.

KKK 